\title{
Heavy metals in private car dust collected from Universiti Malaysia Pahang, Gambang Campus: Contamination and human health risks
}

\author{
J.H. Tay ${ }^{1}$, and N. Zakaria ${ }^{1}$ \\ ${ }^{1}$ Faculty of Industrial Sciences \& Technology, Universiti Malaysia Pahang, 26300 Pahang, Malaysia.
}

\begin{abstract}
A pilot study was conducted to investigate the concentrations of seven heavy metals ( $\mathrm{Zn}, \mathrm{Cu}, \mathrm{Cr}, \mathrm{Cd}, \mathrm{Fe}, \mathrm{Ni}$ and $\mathrm{Pb}$ ) in private car dusts collected from Universiti Malaysia Pahang (UMP), Gambang campus. Ten private cars were selected among UMP staffs and students, and the dust samples were obtained by using a conventional vacuum cleaner with a clean nylon sampling sock pre-inserted into the suction nozzle. All samples were acid-digested with aqua regia solution and analysed for metal concentration using Atomic Absorption Spectrometry (AAS). The highest mean concentrations were recorded for Fe $(650 \pm 480 \mathrm{mg} / \mathrm{kg})$, followed by Zn $(160 \pm 110$ $\mathrm{mg} / \mathrm{kg}), \mathrm{Cu}(76.2 \pm 18.5 \mathrm{mg} / \mathrm{kg}), \mathrm{Pb}(39.2 \pm 99.1 \mathrm{mg} / \mathrm{kg}), \mathrm{Ni}(6.39 \pm 8.30 \mathrm{mg} / \mathrm{kg}), \mathrm{Cr}(3.42 \pm 5.90$ $\mathrm{mg} / \mathrm{kg})$ and $\mathrm{Cd}(0.55 \pm 1.40 \mathrm{mg} / \mathrm{kg})$. Hazard quotient $(\mathrm{HQ})$ and hazard index $(\mathrm{HI})$ values lower than 1 indicated no potential non-carcinogenic risks to the adult drivers.
\end{abstract}

\section{ARTICLE HISTORY}

Received: $18^{\text {th }}$ July 2021

Revised: $6^{\text {th }}$ Sept 2021

Accepted: 24th Nov 2021

\section{KEYWORDS}

Heavy metals

Private car dust

Health risk

\section{INTRODUCTION}

Dust is a heterogenous mixture of organic, inorganic and biological components. Dust in indoor environment has been recognized as a major source and sink of various environmental contaminants, including heavy metals [1-4]. Heavy metals are of concern due to their non-biodegradable nature, toxicities and ability to bioaccumulate. Long term exposure to heavy metals may cause problems to human health, such as cardiovascular and respiratory diseases [5]. Over the past few decades, heavy metal contamination in indoor dust has been extensively studied, particularly in schools [6-8], and residential homes $[1,9,10]$. Heavy metal concentration in indoor dust can be affected by geographical location, anthropogenic activities and buildings' characteristics. Most studies identified oral ingestion as the main exposure pathway for humans, followed by dermal uptake and inhalation $[6,9,11,12]$.

On the other hand, the quality of in-vehicle or in-car microenvironment has not received enough attention although cars have become a basic need in our daily life. Time spent in vehicles can ranged from minutes to several hours per day depending on the traffic condition and travel destinations. Without realizing, people could have exposed to contaminants associated with vehicle interior dust. Much of the current literature on in-vehicle air quality pays particular attention to PM10, PM2.5 and PM1 (particulate matter smaller than 10, 2.5 and $1 \mu \mathrm{m}$, respectively) [13-15], whilst only a few studies focusing on heavy metal contamination in private car dust [16] and settled bus dust $[17,18]$ have been reported. Therefore, the specific aims of this study were to (1) investigate the levels of selected heavy metals in private car dust collected from Universiti Malaysia Pahang; (2) estimate exposure risks associated with the private car dust via ingestion, inhalation and dermal absorption.

\section{MATERIALS AND METHODS}

\section{Sample collection}

Universiti Malaysia Pahang (UMP) is a technical university located in Pahang, Malaysia with a staff and student population of around 14,000. This study was conducted in September 2019 at the Gambang campus $\left(3.7070^{\circ} \mathrm{N}\right.$, $103.1025^{\circ} \mathrm{E}$ ), which is situated in Gambang, near the East Coast Expressway. Ten private sedan cars within were selected among UMP staffs and students ( $\mathrm{n}=4$ and 6 , respectively). The volunteers were required to answer a simple questionnaire regarding their car condition and personal behaviours. All the selected cars were not washed or cleaned for a period of at least one week. Dust samples were collected from the car dashboards, car seats and carpets using a conventional vacuum cleaner with a clean nylon sock inserted to the suction nozzle. After sampling, the nylon sock was removed from suction head and stored in a clean plastic zip bag. The suction head were cleaned with deionized water and air-dried in between each sampling. Upon arrival at the laboratory, foreign objects such as hair and food debris were removed manually using a plastic tweezer. 


\section{Sample and data analysis}

All glassware and plasticware used during the sample preparation were soaked overnight with $5 \%(\mathrm{v} / \mathrm{v}) \mathrm{HNO}_{3}$ and rinsed three times with deionized water to avoid external contamination. Powderless gloves were used during all sampling and laboratory work. About $1 \mathrm{~g}$ of dust sample was acid digested using $10 \mathrm{~mL}$ of aqua regia (analytical grade $\mathrm{HCl} \mathrm{HNO}_{3}$ $=3: 1 \mathrm{v} / \mathrm{v}$ ) solution in boiling tube and heated to $95^{\circ} \mathrm{C}$ for $30-45$ minutes in the water bath. Later, another $2 \mathrm{~mL}$ of aqua regia was added, followed by further heating until no brown fumes were given off from the sample. The mixture was allowed to cool, and $1 \mathrm{~mL}$ of hydrogen peroxide $\left(\mathrm{H}_{2} \mathrm{O}_{2}\right)$ was added to allow complete oxidation of organic matters, followed by further boiling. After cooling, each solution was filtered using a $5 \mathrm{C}$ Whatman filter paper, diluted to $50 \mathrm{~mL}$ with deionized water in a volumetric flask and stored in the refrigerator at $4{ }^{\circ} \mathrm{C}$ until instrumental analysis. Three reagent blanks were determined by completion of the full analytical procedure without samples. Reported results were corrected by the average of blank concentrations. Concentrations of $\mathrm{Pb}, \mathrm{Zn}, \mathrm{Cd}, \mathrm{Fe}, \mathrm{Ni}, \mathrm{Cu}$ and $\mathrm{Cr}$ were determined using an $\mathrm{Atomic}$ Absorption Spectrometer (Perkin Elmer AAnalyst 800). Calibration standards were prepared from ICP multi-element standard solution IV purchased from Merck (Germany) to provide a 5-point working calibration curve. Samples were diluted until their response fell within the calibration range. The instrumental detection limits were determined as 0.002 $\mathrm{mg} / \mathrm{kg}$ for $\mathrm{Cr}, 0.034 \mathrm{mg} / \mathrm{kg}$ for $\mathrm{Ni}, 0.019 \mathrm{mg} / \mathrm{kg}$ for $\mathrm{Pb}, 0.029 \mathrm{mg} / \mathrm{kg}$ for $\mathrm{Zn}, 1.75 \mathrm{mg} / \mathrm{kg}$ for Cu, $0.16 \mathrm{mg} / \mathrm{kg}$ for Fe and $0.011 \mathrm{mg} / \mathrm{kg}$ for Cd. All statistical analyses (Spearman rank correlation, Mann Whitney $U$ test and Kruskal-Wallis $H$ test) were performed using Excel 2016. The significance was set at $\alpha=0.05$ in all the statistical analyses.

\section{Health risk assessment}

The average daily dose (ADD, mg/kg/day) for all target heavy metals were estimated using Equation 1-3, adpated from USEPA Exposure Handbook [19]:

$$
\begin{gathered}
A D D_{\text {ing }}=\frac{C \times I n g R \times E F \times E D}{B W \times A T} \times 10^{-6} \\
A D D_{\text {inh }}=\frac{C \times I n h R \times E F \times E D}{P E F \times B W \times A T} \\
A D D_{\text {der }}=\frac{C \times S A \times A F \times A B S \times E F \times E D}{B W \times A T} \times 10^{-6}
\end{gathered}
$$

Where, $\mathrm{C}$ is the concentration of the element ( $\mathrm{mg} / \mathrm{kg}), \operatorname{IngR}$ is the ingestion rate of contaminated dust (30 mg/day), $\mathrm{EF}$ is the exposure frequency (350 day/year), ED is the exposure duration (5 year), BW is the body weight (70 kg), AT is the average time $\left(\mathrm{ED} \times 365\right.$ day), InhR is the inhalation rate $\left(15.2 \mathrm{~m}^{3} / \mathrm{day}\right)$, $\mathrm{PEF}$ is the inhalation factor for the respirable particles $\left(1.36 \times 10^{9} \mathrm{~m}^{3} / \mathrm{kg}\right), \mathrm{SA}$ is the surface area of the skin exposed to pollutants $\left(6700 \mathrm{~cm}^{2}\right)$, AF is the skin adherence factor $\left(0.07 \mathrm{mg} / \mathrm{cm}^{2} / \mathrm{h}\right)$, ABS is the dermal absorption factor $(0.001)$.

Based on ADDs from the three exposure routes, hazard quotient (HQ) and hazard indexes (HI) indicating the noncancer risk during a lifetime can be calculated according to Equation (4) and (5):

$$
\begin{gathered}
H Q=\frac{A D D}{R f D} \\
H I=\sum H Q=H Q_{i n g}+H Q_{i n h}+H Q_{d e r}
\end{gathered}
$$

Where RfD is the estimated maximum permissible risk on humans through daily exposure (mg/kg/day). The RfD values used for $\mathrm{Cr}$ is $0.003 \mathrm{mg} / \mathrm{kg} / \mathrm{day}, 0.02$ for $\mathrm{Ni}, 0.3$ for $\mathrm{Zn}, 0.04$ for $\mathrm{Cu}, 0.001$ for $\mathrm{Cd}, 0.004$ for $\mathrm{Pb}$ and 0.7 for $\mathrm{Fe}$ [20]. $\mathrm{HQ}$ and $\mathrm{HI} \leq 1$ indicates that adverse effects on human health are unlikely, while HQ and HI > 1 reveals probable adverse health effects.

\section{RESULTS \& DISCUSSION}

The descriptive statistics for heavy metals in private car dust are summarized in Figure 1. Overall, the mean concentrations of heavy metals decreased in the following order: Fe $(645 \pm 480 \mathrm{mg} / \mathrm{kg})>\mathrm{Zn}(164 \pm 110 \mathrm{mg} / \mathrm{kg})>\mathrm{Cu}$ $(76.2 \pm 18.5 \mathrm{mg} / \mathrm{kg})>\mathrm{Pb}(39.2 \pm 99.1 \mathrm{mg} / \mathrm{kg})>\mathrm{Ni}(6.39 \pm 8.30 \mathrm{mg} / \mathrm{kg})>\mathrm{Cr}(3.42 \pm 5.90 \mathrm{mg} / \mathrm{kg})>\mathrm{Cd}(1.37 \pm 2.09 \mathrm{mg} / \mathrm{kg})$. The levels of heavy metal measured in the present study were less than one-half of that reported for settled bus dust [17], which facilitates a large number of passenger flow. High level of Fe in car dust was expected since it is one of the major components of the Earth's crust. Concentrations of Zn ranged between $39.03 \mathrm{mg} / \mathrm{kg}$ and $446.62 \mathrm{mg} / \mathrm{kg}$. The occurrence of $\mathrm{Zn}$ in private car dust might be influenced by street dust as a result of the accummulation of $\mathrm{Zn}$ from wear and tear of 
vulcanized rubber tires, motor oils and vehicle brakes [21, 22]. Although the usage of leaded petrol in Malaysia has been phased out since $1999, \mathrm{~Pb}$ is still present in our environment and being frequently detected in indoor dust samples (Table 1). Our results for $\mathrm{Zn}$ and $\mathrm{Cd}$ were similar to a previous study on private cars from South Africa [16], whilst lower concentrations of $\mathrm{Cr}, \mathrm{Ni}$ and $\mathrm{Cu}$ were recorded in our study. The observed differences could be due to predominant usage of car air conditioners in our study instead of natural ventilation, as fresh air from car windows might exert influence on the metal levels. Other factors that could influence metal concentrations in private car dust include soil/dust particles that adhere to footwear, frequency of cleaning as well as smoking activities. The heavy metal concentrations found in this study $(0.55-645 \mathrm{mg} / \mathrm{kg})$ were generally within the range of values reported for various indoor environments in Malaysia (Table 1).
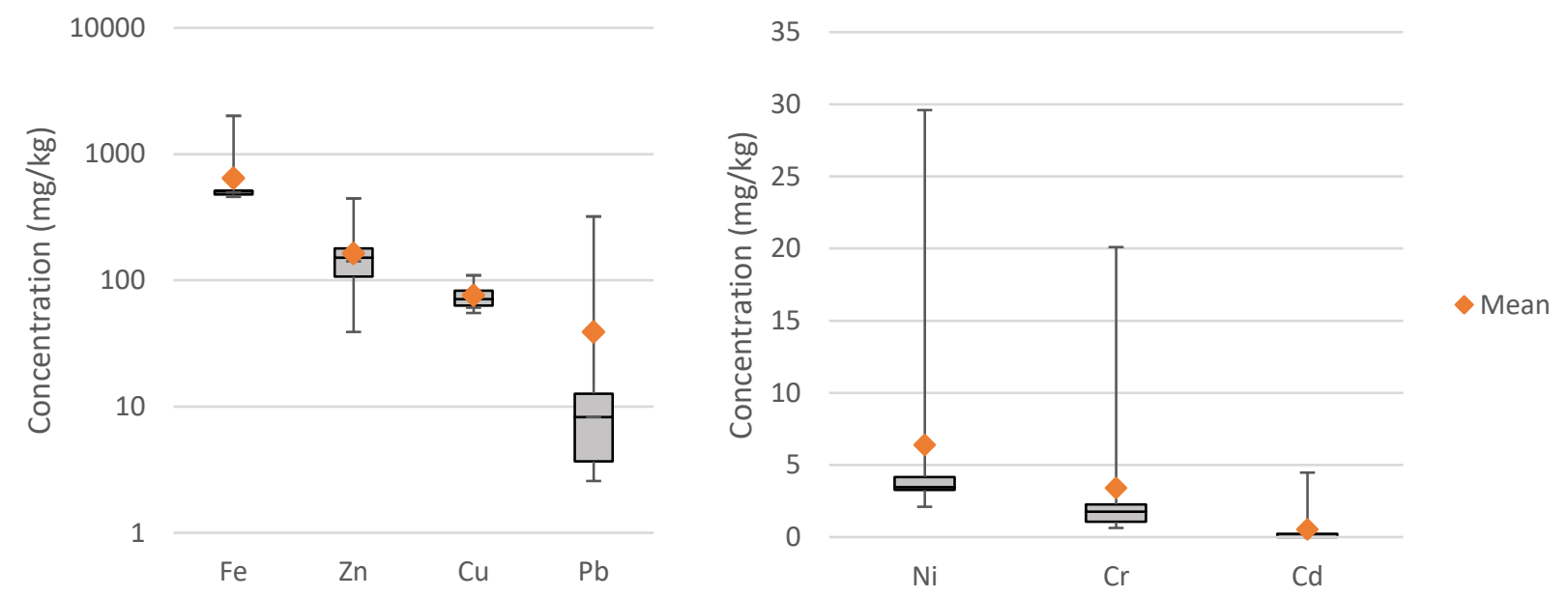

Figure 1. Box-whisker plots of the heavy metal concentration $(\mathrm{mg} / \mathrm{kg})$ in private car dust.

Table 1. Comparison of heavy metal concentrations in dust samples with previous studies.

\begin{tabular}{|c|c|c|c|c|c|c|c|c|c|}
\hline \multirow{2}{*}{$\begin{array}{l}\text { Referenc } \\
\mathrm{e}\end{array}$} & \multirow{2}{*}{ Location } & \multirow{2}{*}{$\begin{array}{l}\text { Type of } \\
\text { dust }\end{array}$} & \multicolumn{7}{|c|}{ Mean concentrations $(\mathrm{mg} / \mathrm{kg})$} \\
\hline & & & $\mathrm{Cr}$ & $\mathrm{Pb}$ & $\mathrm{Zn}$ & $\mathrm{Ni}$ & $\mathrm{Cu}$ & $\mathrm{Cd}$ & $\mathrm{Fe}$ \\
\hline $\begin{array}{l}\text { This } \\
\text { study }\end{array}$ & $\begin{array}{r}\text { UMP } \\
\text { Gambang, } \\
\text { Malaysia }\end{array}$ & $\begin{array}{l}\text { Private } \\
\text { car dust } \\
(\mathrm{n}=10)\end{array}$ & $2^{3.4}$ & $2^{39 .}$ & 165 & $\begin{array}{l}6.3 \\
9\end{array}$ & $2^{76 .}$ & $5^{0.5}$ & 645 \\
\hline $\begin{array}{l}\text { Olowoyo } \\
\text { et al. [16 }{ }^{\mathrm{a}}\end{array}$ & $\begin{array}{l}\text { Pretoria, } \\
\text { South } \\
\text { Africa }\end{array}$ & $\begin{array}{l}\text { Private } \\
\text { car dust } \\
(n=30)\end{array}$ & $\begin{array}{l}64 . \\
4\end{array}$ & $\begin{array}{l}17 . \\
5\end{array}$ & 186 & 25. & 118 & $3^{0.2}$ & n.a. \\
\hline $\begin{array}{l}\text { Lei et al. } \\
{[17]}\end{array}$ & $\begin{array}{l}\text { Harbin, } \\
\text { China }\end{array}$ & $\begin{array}{l}\text { Settled } \\
\text { bus dust } \\
(\mathrm{n}=45)\end{array}$ & $\begin{array}{l}44 . \\
4\end{array}$ & $\begin{array}{l}70 . \\
9\end{array}$ & 328 & $8^{17 .}$ & $\begin{array}{l}87 . \\
9\end{array}$ & $\begin{array}{l}1.6 \\
1\end{array}$ & n.a. \\
\hline $\begin{array}{l}\text { Latif et al. } \\
\text { [23] }\end{array}$ & $\begin{array}{c}\text { Kajang } \\
\text { \& Bandar } \\
\text { Baru Bangi, } \\
\text { Malaysia } \\
\text { Kajang }\end{array}$ & $\begin{array}{l}\text { Nursery } \\
\text { school dust } \\
(n=90)\end{array}$ & $9^{11 .}$ & 254 & 145 & n.a. & n.a. & $\begin{array}{l}0.2 \\
3\end{array}$ & 4800 \\
\hline $\begin{array}{l}\text { Latif et al. } \\
\quad[10]\end{array}$ & $\begin{array}{c}\text { \& Bandar } \\
\text { Baru Bangi, } \\
\text { Malaysia }\end{array}$ & $\begin{array}{r}\text { Househol } \\
\text { d dust }(n=30)\end{array}$ & n.a. & $\begin{array}{l}0.8 \\
5\end{array}$ & 0.43 & $3^{0.8}$ & n.a. & $\begin{array}{l}0.1 \\
9\end{array}$ & 0.69 \\
\hline $\begin{array}{l}\text { Mohd Tahir } \\
\text { et al. [24] }\end{array}$ & $\begin{array}{l}\text { Dungun, } \\
\text { Malaysia }\end{array}$ & $\begin{array}{l}\text { Nursery } \\
\text { school dust } \\
(\mathrm{n}=18)\end{array}$ & n.a. & 78 & 544 & n.a. & $\begin{array}{l}44 . \\
3\end{array}$ & n.a. & 3800 \\
\hline $\begin{array}{c}\text { Praveena et } \\
\text { al. [7] }\end{array}$ & $\begin{array}{c}\text { Sri } \\
\text { Serdang, } \\
\text { Malaysia }\end{array}$ & $\begin{array}{r}\text { Classroo } \\
\mathrm{m} \text { dust }(\mathrm{n}=7)\end{array}$ & n.a. & $\begin{array}{l}89 . \\
1\end{array}$ & n.a. & n.a. & 33 & $9^{1.8}$ & n.a. \\
\hline $\begin{array}{c}\text { Abdul } \\
\text { Wahab et al. } \\
{[25]}\end{array}$ & $\begin{array}{l}\text { Seberan } \\
\text { g Perai, } \\
\text { Malaysia }\end{array}$ & $\begin{array}{r}\text { Househol } \\
\text { d dust }(n=9)\end{array}$ & n.a. & $\begin{array}{l}39 . \\
5\end{array}$ & 33.8 & $2^{18 .}$ & $\begin{array}{l}6.8 \\
4\end{array}$ & n.a. & n.a. \\
\hline
\end{tabular}




\begin{tabular}{|c|c|c|c|c|c|c|c|c|c|}
\hline Sulaiman et & UiTM & $\begin{array}{l}\text { Lecture } \\
\text { room dust } \\
(\mathrm{n}=8)\end{array}$ & n.a. & $4^{17 .}$ & $\begin{array}{l}288 \\
0\end{array}$ & n.a. & $\begin{array}{l}97 . \\
4\end{array}$ & n.a. & $\begin{array}{c}1080 \\
0\end{array}$ \\
\hline al. [26] & $\begin{array}{l}\text { Jengka, } \\
\text { Malaysia }\end{array}$ & $\begin{array}{l}\text { University } \\
\text { hostel dust } \\
(\mathrm{n}=8)\end{array}$ & n.a. & $2^{8.7}$ & $\begin{array}{l}390 \\
0\end{array}$ & n.a. & 137 & n.a. & $\begin{array}{c}5070 \\
0\end{array}$ \\
\hline $\begin{array}{c}\text { Darus et al. } \\
\text { [27] }\end{array}$ & $\begin{array}{l}\text { Shah } \\
\text { Alam, } \\
\text { Malaysia }\end{array}$ & $\begin{array}{l}\text { Nursery } \\
\text { school dust } \\
(\mathrm{n}=9)\end{array}$ & $9^{16 .}$ & $2^{31 .}$ & 149 & $0^{9.0}$ & $2^{30 .}$ & n.a. & 4230 \\
\hline
\end{tabular}

n.a.: data not available

${ }^{a}$ Values were obtained by averaging individual concentrations of heavy metals from 30 private car dust samples.

${ }^{b}$ Values were obtained by averaging mean concentrations of heavy metals from town $(n=7)$, industrial $(n=6)$ and village $(\mathrm{n}=5)$ indoor dust samples.

Spearman rank correlation tests were performed to identify correlations between individual heavy metals in the samples. High positive correlations $(0.68<r<0.85, p<0.05)$ were observed between $\mathrm{Fe}-\mathrm{Zn}, \mathrm{Fe}-\mathrm{Ni}$ and $\mathrm{Zn}-\mathrm{Ni}$ in dust samples (Table 2), suggesting a common source of origin for these metals. However, no significant difference in heavy metal concentrations in car dust samples was found between cars owned by staff and students (Mann Whitney $U$ test, $p$ $>0.05)$. Furthermore, Kruskal-Wallis $H$ test revealed no significant difference between heavy metal concentrations and car age $(p>0.05)$, which could be attributed to the small number of samples available for this study.

Table 2. Correlation matrix for heavy metal concentrations

\begin{tabular}{cccccccc}
\hline & $\mathrm{Fe}$ & $\mathrm{Zn}$ & $\mathrm{Cu}$ & $\mathrm{Pb}$ & $\mathrm{Ni}$ & $\mathrm{Cr}$ & $\mathrm{Cd}$ \\
\hline $\mathrm{Fe}$ & 1 & & & & & & \\
$\mathrm{Zn}$ & $\mathbf{0 . 8 5 *}_{\mathrm{n}}^{*}$ & 1 & & & & & \\
$\mathrm{Cu}$ & 0.62 & 0.37 & 1 & & & & \\
$\mathrm{~Pb}$ & 0.20 & 0.25 & 0.04 & 1 & & & \\
$\mathrm{Ni}$ & $\mathbf{0 . 6 8}^{*}$ & $\mathbf{0 . 7 3}$ & 0.12 & 0.54 & 1 & & \\
$\mathrm{Cr}$ & 0.50 & 0.39 & 0.13 & 0.55 & 0.62 & 1 & \\
$\mathrm{Cd}$ & 0.05 & -0.16 & 0.37 & 0.02 & 0.05 & -0.28 & 1 \\
\hline
\end{tabular}

*Correlation is significant at the 0.05 level (2-tailed).

Figure 2 shows the HQ and HI values for non-carcinogenic risks to adult driver. The HI values decreased in the following order: $\mathrm{Pb}>\mathrm{Cu}>\mathrm{Cr}>\mathrm{Fe}>\mathrm{Zn}, \mathrm{Cd}>\mathrm{Ni}$. A similar order of $\mathrm{HI}$ values $(\mathrm{Pb}>\mathrm{Cr}>\mathrm{Cd}>\mathrm{Ni}$ ) was reported for settled bus dust exposure in China [17], while a decreasing trend of $\mathrm{Zn}>\mathrm{Cr}>\mathrm{Ni}$ was reported for private car dust exposure in South Africa [16]. However, HQ and HI values in the present study were much higher due to differences in parameters used for average daily dose assessment (ADD), therefore these data must be interpreted with caution. For all target heavy metals, HQ values obtained in this present study were still several orders of magnitude lower than the RfD. HI values lower than 1 indicated negligible non-carcinogenic risks to our adult drivers. In general, our results showed that ingestion was the major route of exposure for all the studied heavy metals, followed by dermal absorption and inhalation. These results are in line with those of previous studies focusing on indoor dust. 


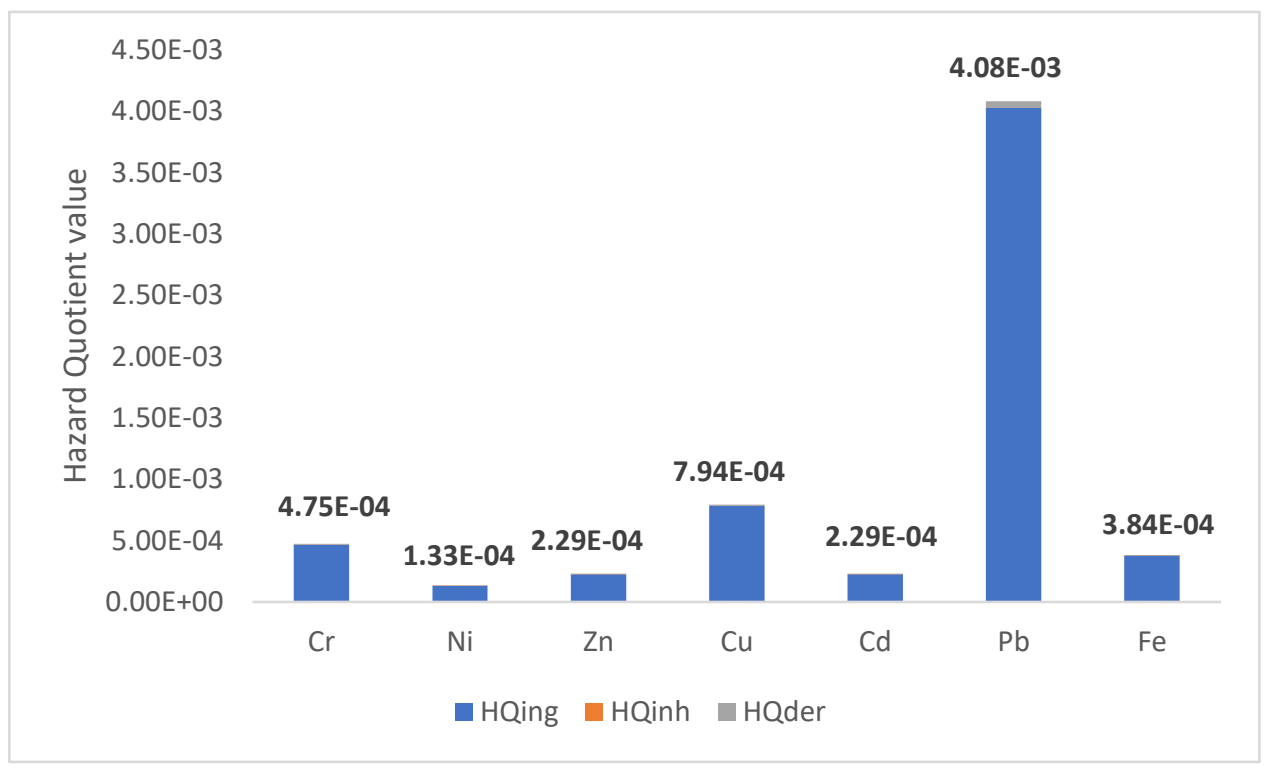

Figure 2. Hazard quotients and hazard index for non-carcinogenic risk to adult drivers estimated from heavy metals in private car dust (Bold values indicate $\mathrm{HI}$ ).

\section{CONCLUSION}

The present study investigated the levels of $\mathrm{Zn}, \mathrm{Cr}, \mathrm{Cd}, \mathrm{Cu}, \mathrm{Fe}, \mathrm{Ni}$ and $\mathrm{Pb}$ in 10 private car dust samples collected from Universiti Malaysia Pahang, Gambang campus. Results showed that the mean concentrations of heavy metals in private car dust decreased in the following order: $\mathrm{Fe}>\mathrm{Zn}>\mathrm{Cu}>\mathrm{Pb}>\mathrm{Ni}>\mathrm{Cr}>\mathrm{Cd}$. Health risk assessment showed no potential non-carcinogenic risks to the adult drivers. However, there are several limitations in our study. For example, only a small number of samples $(\mathrm{n}=10)$ from Universiti Malaysia Pahang Gambang campus were included in our study and thus not representative of the general population in the district of Kuantan, Pahang. Health risk assessment was conducted based on average values reported in the literature without taking into account the socio-demographic information from volunteers involved in the study. Therefore, a more comprehensive future research is recommended to investigate the relationship between heavy metal concentrations in vehicle dust of different vehicle size class and types of fuel used.

\section{ACKNOWLEDGEMENT}

The authors would like to thank all the volunteers for their help in sample collection. Financial supports from the Faculty of Industrial Sciences \& Technology (FIST), UMP through a grant for final year project students (NZ) is kindly acknowledged.

\section{REFERENCES}

[1] Chattopadhyay, G., K.C.-P. Lin, and A.J. Feitz, Household dust metal levels in the Sydney metropolitan area. Environmental Research, 2003. 93(3): p. 301-307.

[2] Hejami, A.A., et al., Heavy metals in indoor settled dusts in Toronto, Canada. Science of The Total Environment, 2020. 703: p. 134895.

[3] Tan, S.Y., et al., A review of heavy metals in indoor dust and its human health-risk implications. Rev Environ Health, 2016. 31(4): p. 447-456.

[4] Shi, T. and Y. Wang, Heavy metals in indoor dust: Spatial distribution, influencing factors, and potential health risks. Science of The Total Environment, 2021. 755: p. 142367.

[5] Khan, R.K. and M.A. Strand, Road dust and its effect on human health: a literature review. Epidemiol Health, 2018. 40: p. e2018013.

[6] Tan, S.Y., et al., Heavy metal quantification of classroom dust in school environment and its impacts on children health from Rawang (Malaysia). Environmental Science and Pollution Research, 2018. 25(34): p. 34623-34635.

[7] Praveena, S.M., N.S. Abdul Mutalib, and A.Z. Aris, Determination of Heavy Metals in Indoor Dust From Primary School (Sri Serdang, Malaysia): Estimation of the Health Risks. Environmental Forensics, 2015. 16(3): p. 257-263.

[8] Moghtaderi, M., et al., The Safety of Schools Based on Heavy Metal Concentrations in Classrooms' Dust: A Systematic Review and Meta-Analysis. Iranian journal of public health, 2020. 49(12): p. 2287-2294. 
[9] Cheng, Z., et al., Characteristics and health risk assessment of heavy metals exposure via household dust from urban area in Chengdu, China. Science of The Total Environment, 2018. 619-620: p. 621-629.

[10] Latif, M.T., et al., Composition of Household Dust in Semi-urban Areas in Malaysia. Indoor and Built Environment, 2009. 18(2): p. 155-161.

[11] Kurt-Karakus, P.B., Determination of heavy metals in indoor dust from Istanbul, Turkey: Estimation of the health risk. Environment International, 2012. 50: p. 47-55.

[12] Lin, Y., et al., Pollution distribution and health risk assessment of heavy metals in indoor dust in Anhui rural, China. Environmental Monitoring and Assessment, 2015. 187(9): p. 565.

[13] Gulliver, J. and D.J. Briggs, Personal exposure to particulate air pollution in transport microenvironments. Atmospheric Environment, 2004. 38(1): p. 1-8.

[14] Yang, F., et al., Heterogeneity of passenger exposure to air pollutants in public transport microenvironments. Atmospheric Environment, 2015. 109: p. 42-51.

[15] Okokon, E.O., et al., Particulates and noise exposure during bicycle, bus and car commuting: A study in three European cities. Environmental Research, 2017. 154: p. 181-189.

[16] Olowoyo, J.O., O.O. Agboola, and A.E. Alaba, Health risk assessment of toxic trace metals in private car dusts from Pretoria, South Africa. Nature Environment and Pollution Technology, 2018. 17(2): p. 525-531.

[17] Lei, T., et al., Trace metals in resuspended fraction of settled bus dust and assessment of non-occupational exposure. Ecotoxicology and Environmental Safety, 2016. 130: p. 214-223.

[18] Gao, P., et al., Assessment on the occupational exposure of urban public bus drivers to bioaccessible trace metals through resuspended fraction of settled bus dust. Science of The Total Environment, 2015. 508: p. 37-45.

[19] USEPA, Exposure Factors Handbook. 2011, U.S. Environmental Protection Agency, Washington, DC.

[20] United States of Environmental Protection Agency (USEPA). Integrated risk information system. Washington, DC: US EPA, 2011. Available at: http://www.epa.gov/IRIS/.

[21] Fergusson, J.E. and N.D. Kim, Trace elements in street and house dusts: sources and speciation. Science of The Total Environment, 1991. 100: p. 125-150.

[22] Han, X. and X. Lu, Spatial distribution, environmental risk and source of heavy metals in street dust from an industrial city in semi-arid area of China. Archives of Environmental Protection, 2017. 43(2): p. 10-19.

[23] Latif, M.T., et al., Composition of heavy metals in indoor dust and their possible exposure: a case study of preschool children in Malaysia. Air Quality, Atmosphere \& Health, 2013. 7(2): p. 181-193.

[24] Tahir, N.M., P.S. Chee, and M. Jaafar, Determination of heavy metals content in soils and indoor dusts from nurseries in Dungun, Terengganu. The Malaysian Journal of Analytical Sciences, 2007. 11(1): p. 280-286.

[25] Wahab, N.M.A., et al., Heavy metal concentration of settled surface dust in residential building. The Malaysian Journal of Analytical Sciences, 2012. 16(1): p. 18-23.

[26] Sulaiman, F.R., et al., Assessment of heavy metals in indoor dust of a university in a tropical environment. Environmental Forensics, 2017. 18(1): p. 74-82.

[27] Darus, F.M., et al., Heavy Metals Composition of Indoor Dust in Nursery Schools Building. Procedia - Social and Behavioral Sciences, 2012. 38: p. 169-175. 